(c) American Dairy Science Association, 2004.

\title{
Differential Effects of Interferon- $\tau$ on the Prostaglandin Synthetic Pathway in Bovine Endometrial Cells Treated with Phorbol Ester*
}

\author{
A. Guzeloglu, F. Michel, and W. W. Thatcher \\ Department of Animal Sciences, University of Florida, Gainesville 32611
}

\section{ABSTRACT}

Rationale for these experiments was to evaluate the dose effects of bovine interferon- $\tau$ (IFN- $\tau$ ) on the prostaglandin secretory pathway of immortalized bovine endometrial (BEND) cells in response to phorbol 12, 13dibutyrate $(\mathrm{PdBu})$ and to characterize similar responses in primary bovine uterine epithelial cells as a biomonitor of embryo-induced antiluteolytic effects on the endometrium. The BEND cells were treated with $\mathrm{PdBu}(0$ or $100 \mathrm{ng} / \mathrm{mL}$ ) and IFN- $\tau(0$ or $50 \mathrm{ng} / \mathrm{mL}$ ) for $6 \mathrm{~h}$. The $\mathrm{PdBu}$ stimulated secretions of $\mathrm{PGF}_{2 \alpha}$ and prostaglandin $\mathrm{E}_{2}\left(\mathrm{PGE}_{2}\right)$. Co-treatment of cells with IFN- $\tau$ blocked $\mathrm{PdBu}$-induced secretion of both $\mathrm{PGF}_{2 \alpha}$ and $\mathrm{PGE}_{2}$. Treatment with $\mathrm{PdBu}$ for $6 \mathrm{~h}$ induced expression of prostaglandin $\mathrm{H}$ synthase- 2 mRNA, prostaglandin $\mathrm{H}$ synthase-2 protein, and prostaglandin $\mathrm{E}$ synthase mRNA, which were blocked with concurrent addition of IFN- $\tau$. Doses of IFN- $\tau(0.05,0.5,1,5,10$, and $20 \mu \mathrm{g} /$ $\mathrm{mL}$ ) were used with $\mathrm{PdBu}(0$ and $100 \mathrm{ng} / \mathrm{mL})$. The IFN$\tau$ alone failed to stimulate secretion of $\mathrm{PGF}_{2 \alpha}$ and $\mathrm{PGE}_{2}$, whereas IFN- $\tau$ doses $<5 \mu \mathrm{g} / \mathrm{mL}$ suppressed PdBu-stimulated secretions of $\mathrm{PGF}_{2 \alpha}$ and $\mathrm{PGE}_{2}$. Uterine epithelial cells were isolated from cows at $\mathrm{d} 17$ after estrus and were cultured to confluence in serum-free medium. Cells were treated with IFN- $\tau(0,50$, or $500 \mathrm{ng} / \mathrm{mL})$ and $\mathrm{PdBu}(0$ or $100 \mathrm{ng} / \mathrm{mL}$ ) before media were collected after $24 \mathrm{~h}$ for $\mathrm{PGF}_{2 \alpha}$ and $\mathrm{PGE}_{2}$ analyses. Treatment of primary uterine epithelial cells with $\mathrm{PdBu}$ induced $\mathrm{PGF}_{2 \alpha}$ secretion, and IFN- $\tau(50$ and $500 \mathrm{ng} / \mathrm{mL}$ ) caused a reduction in $\mathrm{PGF}_{2 \alpha}$ secretion induced by $\mathrm{PdBu}$. In the absence of $\mathrm{PdBu}, \mathrm{IFN}-\tau$ increased basal secretion of $\mathrm{PGF}_{2 \alpha}$. Concentrations of $\mathrm{PGE}_{2}$ increased in response to $\mathrm{PdBu}$, and the $50-\mathrm{ng} / \mathrm{mL}$ dose of IFN- $\tau$ had a stimulatory effect on $\mathrm{PGE}_{2}$ concentrations compared with the $500-\mathrm{ng} / \mathrm{mL}$ dose in the absence of PdBu. Phorbol esterinduced gene transcription as related to prostaglandin synthesis is regulated by IFN- $\tau$ in vitro.

\footnotetext{
Received December 9, 2003.

Accepted February 20, 2004.

Corresponding author: W. W. Thatcher; e-mail: thatcher@ animal.ufl.edu.

* This is Florida Agricultural Experimental Station Journal Series No.R-10043.
}

(Key words: bovine, endometrial cells, interferon- $\tau$, prostaglandins)

Abbreviation key: BEND = immortalized bovine endometrial, GAPDH = glyceraldehyde 3-phosphate dehydrogenase, IFN- $\boldsymbol{\tau}=$ interferon- $\tau$, IRF-1 = interferon regulatory factor $-1, \mathbf{P d B u}=$ phorbol 12, 13-dibutyrate, $\mathbf{P G E}_{2}=$ prostaglandin $\mathrm{E}_{2}, \mathbf{P G E S}=$ prostaglandin $\mathrm{E}$ synthase, PGHS-2 = prostaglandin $\mathrm{H}$ synthase-2, $\mathbf{P K C}=$ protein kinase $\mathrm{C}$.

\section{INTRODUCTION}

Different experimental models have been used to document the effect of interferon- $\tau(\mathbf{I F N}-\tau)$ on $\mathrm{PGF}_{2 \alpha}$ secretion from the bovine endometrium (Danet-Desnoyers et al., 1994; Meyer et al., 1995; Xiao et al., 1998). However, these in vivo and in vitro studies involved extensive animal handling and were time and resource consuming. Also, collection of endometrial cells from cows at different stages of the estrous cycle might have contributed to variable results and interpretations. For example, IFN- $\tau$ has been reported to both inhibit and stimulate secretion of $\mathrm{PGF}_{2 \alpha}$ and expression of prostaglandin H synthase-2 (PGHS-2; Asselin et al., 1997; Xiao et al., 1999; Parent et al., 2003). Spontaneously immortalized bovine endometrial (BEND) cells provide a cell model to elucidate mechanisms regulating secretion of prostaglandins.

The BEND cells were derived from the uterine endometrium of a cow on d 14 of the estrous cycle (Staggs et al., 1998). These cells are responsive to treatments with IFN- $\tau$. A variety of genes and proteins, which were detected in the endometrium from pregnant cows such as interferon regulatory factor-1 (IRF-1), interferonstimulated gene 17/ubiquitin cross-reactive protein, and granulocyte chemotactic protein-2 were expressed by BEND cells in response to IFN- $\tau$ (Austin et al., 1996; Hansen et al., 1997; Staggs et al., 1998; Johnson et al., 1999; Perry et al., 1999; Binelli et al., 2001). Treatment of BEND cells with IFN- $\tau$ activates the JAK-STAT pathway leading to tyrosine phosphorylation, dimer formation, nuclear translocation, and DNA binding of STAT proteins as described elsewhere in detail (Binelli et al., 2001). These responses indicate that BEND cells are 
a potential model for studying IFN- $\tau$-mediated signal transduction systems.

The BEND cells in the resting phase do not secrete prostaglandins, but respond to phorbol 12, 13-dibutyrate $(\mathbf{P d B u})$, a pharmacological activator of protein kinase $\mathrm{C}(\mathbf{P K C})$ to secrete $\mathrm{PGF}_{2 \alpha}$ (Binelli et al., 2000). Treatment of these cells with $\mathrm{PdBu}$ induces expression of PGHS-2 mRNA and PGHS-2 protein (Binelli et al., 2000; Pru et al., 2001; Badinga et al., 2002). Expression of these genes and proteins lead to secretion of $\mathrm{PGF}_{2 \alpha}$.

A model was developed by Binelli et al. (2000) in which PdBu-induced secretion of $\mathrm{PGF}_{2 \alpha}$ in BEND cells was blocked by co-treatment of the cells with IFN- $\tau$. A similar model was applied to primary cultures of endometrial epithelial cells collected from cows at $d 1$ to 3 of the estrous cycle (Xiao et al., 1999). Similar to responses in BEND cells, phorbol ester-induced secretion of $\mathrm{PGF}_{2 \alpha}$ and expression of PGHS-2 protein after a 12 -h period of stimulation and co-treatment with IFN$\tau$ blocked these responses. Also, treatment of cells with IFN- $\tau$ alone did not increase either secretion of $\mathrm{PGF}_{2 \alpha}$ or expression of PGHS-2 protein.

Primary bovine uterine epithelial cells were reported to respond differentially to IFN- $\tau$ such that low doses inhibited basal $\mathrm{PGF}_{2 \alpha}$ secretion and high doses $(10 \mu \mathrm{g} /$ $\mathrm{mL}$ ) stimulated prostaglandin $\mathrm{E}_{2}\left(\mathbf{P G E}_{2}\right)$ (Asselin and Fortier, 2000). Parent et al. (2003) demonstrated that bovine primary uterine epithelial cells respond to oxytocin to induce secretion of $\mathrm{PGF}_{2 \alpha}$, whereas phorbol ester induces secretion of $\mathrm{PGE}_{2}$. In the same study, 5 different variants of bovine (rb-1a, rb-2b, rb3b) and ovine (ro-4 and ro-11) IFN- $\tau$ blocked both oxytocin- and phorbol ester-induced secretion of these prostaglandins. However, a reversal of inhibition was observed when rb-1a, ro- 4 , and ro-11 were used at high concentrations of 20 $\mu \mathrm{g} / \mathrm{mL}$ in the presence of phorbol ester. Regardless of high or low doses, all 5 isoforms of IFN- $\tau$ inhibited oxytocin-induced $\mathrm{PGF}_{2 \alpha}$ secretion in epithelial cells. Oxytocin-induced expression of PGHS-2 protein also was decreased by all isoforms $(20 \mu \mathrm{g} / \mathrm{mL}$; Parent et al., 2003).

Objectives of our study were 1) to document changes in components of the prostaglandin synthetic pathway of BEND cells in response to $\mathrm{PdBu}$ and $\mathrm{IFN}-\tau, 2$ ) to determine prostaglandin secretion profiles of BEND cells in response to a broad range of IFN- $\tau$ doses, and 3) for comparative purposes, to test effects of $\mathrm{PdBu}$ and IFN- $\tau$ on primary bovine uterine epithelial cells.

\section{MATERIALS AND METHODS}

\section{Materials}

Recombinant bovine IFN- $\tau$ 1a $\left(1.08 \times 10^{7} \mathrm{U}\right.$ of antiviral activity/mg) was a generous gift from R. Michael
Roberts (University of Missouri, Columbia). Trizol (Promega, Madison, WI) was purchased along with polystyrene tissue culture Costar 6-well plates, culture dishes $(100 \times 20$; Corning Glass Works, Corning, NY), and polystyrene cell-culture flasks $\left(175 \mathrm{~cm}^{2}\right.$; Sarstedt, Inc., Newton, NC). Twenty-four-well cluster dishes coated with rat-tail collagen were from Becton Dickinson (Bedford, MA). Acrylamide, N, N'-methylenebisacrylamide, sodium dodecyl sulfate, and Nonidet-P40 (BDH Laboratory Supplies, Poole, UK), coomassie brilliant blue, bromophenol blue, $\beta$-mercaptoethanol, $\mathrm{NaOH}$, Tris, TrisHCl, TEMED, ammonium persulfate, formaldehyde, acetic acid, Tween 20, NaCl, EDTA, NaF, glycerol, glycine, and methanol (Fisher Scientific, Pittsburgh, PA) were acquired. The DMEM/Ham's F-12, insulin, transferrin, sodium selenite, hydrocortisone, retinol, Lascorbic phosphate magnesium salt, $\mathrm{PdBu}$, Ham F-12, Eagle minimum essential medium, antibiotic-antimycotic solution, insulin, D-valine, horse serum, aprotinin, leupeptin, pepstatin, $\mathrm{Na}_{4} \mathrm{P}_{2} \mathrm{O}_{7}$, ethylene glycol-bis[ $\beta$ aminoethyl ether]-NNN'N'-tetraacetic acid, $\mathrm{Na}_{3} \mathrm{VO}_{4}$, phenylmethylsulfonyl fluoride, actinomycin $\mathrm{D}$, and bovine serum albumin were from Sigma Chemical Co. (St. Louis, MO). Isotopically labeled $[5,6,8,11,12,14$, $\left.15-{ }^{3} \mathrm{H}\right]-\mathrm{PGF}_{2 \alpha}$ and $-\mathrm{PGE}_{2}$ and nitrocellulose membrane (Hybond-ECL) were from Amersham Corp. (Arlington Heights, IL). Antibody for PGHS-2 (Cayman Chemical, Ann Arbor, MI) was purchased. X-ray film was from Eastman Kodak Co. (X-Omat Blue XB-1; Rochester, NY). Nonfat dried milk was from Mid-America Farms (Springfield, MO). Fetal bovine serum was acquired from Atlanta Biologicals (Norcross, GA). The ultrasensitive hybridization buffer (ULTRAhyb ${ }^{\text {TM}}$; Cat \# 8670; Ambion Inc., The RNA company, Austin, TX), dCTP $\alpha$ ${ }^{32} \mathrm{P}$ (cat \# 33004x01) and Biotrans Nylon membrane (ICN, Irvine, CA) were purchased. Enhanced chemiluminescence kit (Renaissance Western Blot Chemiluminescence Reagent Plus) was from NEN Life Science Products (Boston, MA).

\section{BEND Cell Culture}

Isolation of BEND cells from a primary cell culture is described by Staggs et al. (1998). The cell line is deposited and characterized by the American Type Culture Collection (ATCC number CRL-2398; ATCC, Manassas, VA). The ATCC describes methodology for subculturing, propagation, and freezing of BEND cells. The BEND cells were plated on $100-\mathrm{mm}$ culture plates $(4 \times$ $10^{4}$ cell $\left./ \mathrm{mL}\right)$ in culture medium $(40 \%$ [vol/vol] Ham F$12,40 \%$ [vol/vol] MEM, $10 \mathrm{~mL}$ antibiotic-antimycotic solution/L, $200 \mathrm{IU}$ insulin/L, 0.0343g D-valine/L, 10\% [vol/vol] fetal bovine serum, and 10\% [vol/vol] horse serum) for Experiment 1 and in 35-mm 6-well plates 
$\left(4 \times 10^{4}\right.$ cells $\left./ \mathrm{mL}\right)$ for Experiment 2. Cells were grown to confluency at $37^{\circ} \mathrm{C}$ under a humidified atmosphere containing $95 \%$ air and $5 \% \mathrm{CO}_{2}$, washed in serum-free medium, and cultured for an additional $24 \mathrm{~h}$ in serumfree medium. After this time (designated as $0 \mathrm{~h}$ ), cells were washed again, and serum-free medium was mixed with appropriate treatments and added to cells. Concentrations of $\mathrm{PGF}_{2 \alpha}$ and $\mathrm{PGE}_{2}$ were measured in media as described subsequently.

\section{Preparation of Primary Bovine Uterine Epithelial Cell Cultures}

Nonlactating cyclic cows $(n=7)$ were injected with GnRH (100 $\mu \mathrm{g}$ i.m.) on $\mathrm{d}-9$ (d $0=$ day of preovulatory surge of luteinizing hormone induced by $\mathrm{GnRH}$ ) followed $7 \mathrm{~d}$ later $(\mathrm{d}-2)$ by an injection of $\mathrm{PGF}_{2 \alpha}(25 \mathrm{mg}$ i.m.). At $48 \mathrm{~h}$ after injection of $\mathrm{PGF}_{2 \alpha}, \mathrm{GnRH}$ (d 0) was administered. Cows were slaughtered on d 17. Reproductive tracts were collected, flushed with $40 \mathrm{~mL}$ of PBS, placed on ice, and taken to the laboratory. The uterine horn contralateral to the corpus luteum was used to harvest endometrial epithelial cells. Protocol for endometrial epithelial cell culture in a serum-free system was developed by Takahashi et al. (2001). Briefly, each uterine horn was first tied with surgical suture at the oviductal end and filled with $40 \mathrm{~mL}$ of $0.76 \%$ EDTA-PBS (calcium-and magnesium free; $\mathrm{pH}$ 7.4) from the cervical end. The cervical end of the horn was then tied, and the uterine horn was incubated for $2 \mathrm{~h}$ at $37^{\circ} \mathrm{C}$ in a dish filled with Hank's balanced salt solution (calcium and magnesium free). Then, each uterine horn was cut vertically through the mesometrial lining, and the uterine lumen was exposed. Endometrial epithelium was scraped off by a surgical blade, collected in DMEM/Ham's F-12 media supplemented with $0.1 \%$ (wt/vol) collagenase, filtered, and centrifuged for $10 \mathrm{~min}$ at $100 \times \mathrm{g}$. Epithelial cells were resuspended in serum-free DMEM/Ham's F-12 media supplemented with insulin $(10 \mu \mathrm{g} / \mathrm{mL})$, transferrin $(10 \mu \mathrm{g} / \mathrm{mL})$, sodium selenite $(25 \mathrm{nM})$, hydrocortisone $(100 \mathrm{ng} / \mathrm{mL})$, retinol (10 ng/mL), $L$-ascorbic acid phosphate magnesium salt $(100 \mu \mathrm{M})$, penicillin $(100 \mathrm{IU} / \mathrm{mL})$, and streptomycin $(100$ $\mu \mathrm{g} / \mathrm{mL}$ ). The cells were then plated at $1 \times 10^{6}$ cells per well in 24-well cluster dishes coated with rat-tail collagen and cultured in the DMEM/Ham's F-12 culture medium under an atmosphere of $5 \% \mathrm{CO}_{2}$ in air at $37^{\circ} \mathrm{C}$. Culture media were changed every 2 to $3 \mathrm{~d}$. Confluent cells were observed under the microscope and had characteristics of epithelial cells (i.e., cuboidal morphology as opposed to an absence of spindle-shaped stromal cells). Takahashi et al. (2001) demonstrated that cultured cells were immunocytochemically positive for cytokeratin and negative for vimentin staining.

\section{Experimental Designs}

Experiment 1. The objective was to characterize in BEND cells the changes in secretion of prostaglandins as well as mRNA expression for PGHS-2 and prostaglandin E synthase (PGES) and protein synthesis of PGHS-2 in response to PdBu and IFN- $\tau$.

Following $24 \mathrm{~h}$ of starvation, cells were treated with $\mathrm{PdBu}(0$ or $100 \mathrm{ng} / \mathrm{mL}$ ) and IFN- $\tau(0$ or $50 \mathrm{ng} / \mathrm{mL}$ ) for $6 \mathrm{~h}$. The BEND cells were plated on $100-\mathrm{mm}$ culture plates, and 2 plates per treatment were used each time. After $6 \mathrm{~h}$ of treatment, medium was collected for measurements of $\mathrm{PGF}_{2 \alpha}$ and $\mathrm{PGE}_{2}$ concentrations and cells well harvested for total RNA and protein. This experiment was replicated twice.

Experiment 2. The objective was to characterize $\mathrm{PGF}_{2 \alpha}$ and $\mathrm{PGE}_{2}$ secretory responses of BEND cells to $\mathrm{PdBu}$ and increasing doses of IFN- $\tau$. Following $24 \mathrm{~h}$ of starvation, cells received $\mathrm{PdBu}(0$ or $100 \mathrm{ng} / \mathrm{mL})$ and $0,0.05,0.5,1,5,10$, or $20 \mu \mathrm{g} / \mathrm{mL}$ of IFN- $\tau$. Cells were treated for $24 \mathrm{~h}$, and medium was collected at $24 \mathrm{~h}$ for $\mathrm{PGF}_{2 \alpha}$ and $\mathrm{PGE}_{2}$ measurements. The BEND cells were plated on $35-\mathrm{mm} 6$-well plates, and 3 wells per treatment were assigned. This experiment was replicated twice.

Experiment 3. The objective was to determine responsiveness of primary bovine uterine epithelial cells to $\mathrm{PdBu}$ and IFN- $\tau$. Epithelial cells, at 90\% confluency, were treated (i.e., 4 wells per treatment) in a factorial design with $\mathrm{PdBu}(0$ and $100 \mathrm{ng} / \mathrm{mL}$ ), and $\operatorname{IFN}-\tau(0,50$, or $500 \mathrm{ng} / \mathrm{mL}$ ). Medium was collected after $24 \mathrm{~h}$ for measurements of $\mathrm{PGF}_{2 \alpha}$ and $\mathrm{PGE}_{2}$.

\section{RNA Isolation and Northern Blotting}

Total RNA was isolated from confluent BEND cells with Trizol according to the manufacturer's specifications. Twenty micrograms of cellular RNA were fractionated in a $1.5 \%$ agarose-formaldehyde gel, stained with ethidium bromide, and blotted to BioTrans nylon. Following blotting, RNA was cross-linked by UV radiation and baked at $80^{\circ} \mathrm{C}$ for $1 \mathrm{~h}$. The blots were prehybridized with ULTRAhyb ${ }^{\mathrm{TM}}$ buffer for $1 \mathrm{~h}$ at $42^{\circ} \mathrm{C}$ and hybridized with random primer- $\mathrm{P}^{32}$-labeled $\mathrm{cDNA}$ probes overnight at $42^{\circ} \mathrm{C}$. The PGHS-2 (Liu et al., 2001) cDNA was a gift from Dr. J. Sirois (Canada). A set of primers (F $5^{\prime}$ GCGCGCTGCTGGTCATCAAA $3^{\prime}$ and $\mathrm{R} \quad 5^{\prime}$ GTGTAGGCCAGGGAGCGGGT $3^{\prime}$ ) was synthesized based on sequences from PGES mRNA (Gen Bank Accession \#AY 032727; Fillion et al., 2001), and the PGES cDNA was prepared.

\section{Western Blotting for PGHS-2}

At the end of culture periods, plates were transported to a cold room $\left(4^{\circ} \mathrm{C}\right)$, culture medium was discarded, 
and cells were rinsed twice in ice-cold PBS. Cells were scraped from plates in the presence of $1 \mathrm{~mL}$ of whole cell extract buffer (50 $\mathrm{m} M$ Tris [pH 8.0], $300 \mathrm{~m} M \mathrm{NaCl}$, $20 \mathrm{~m} M \mathrm{NaF}, 1 \mathrm{~m} M \mathrm{Na}_{3} \mathrm{VO}_{4}, 1 \mathrm{~m} M \mathrm{Na}_{4} \mathrm{P}_{2} \mathrm{O}_{7}, 1 \mathrm{~m} M$ EDTA, $1 \mathrm{~m} M$ ethylene glycol-bis[ $\beta$-aminoethyl ether]$\mathrm{NNN}^{\prime} \mathrm{N}^{\prime}$-tetraacetic acid, $0.5 \mathrm{~m} M$ phenylmethylsulfonyl fluoride, $10 \% \mathrm{vol} / \mathrm{vol}$ glycerol, $0.5 \% \mathrm{vol} / \mathrm{vol} \mathrm{NP}-40$, and $10 \mu \mathrm{g} / \mathrm{mL}$ each of aprotinin, leupeptin, and pepstatin) and placed on a rotator (LabQuake, Labindustries, Berkeley, CA) for $30 \mathrm{~min}$ at $4^{\circ} \mathrm{C}$. Lysates were then centrifuged at $10,000 \times g$ for $10 \mathrm{~min}$, and supernatants were collected. Protein concentrations were determined in supernatants by the Bradford method (Bradford, 1976).

Fifty micrograms of protein were loaded onto a $7.5 \%$ acrylamide nondenaturing gel, submitted to SDSPAGE, and electrophoretically transferred to nitrocellulose membranes. Membranes were blocked for $2 \mathrm{~h}$ at room temperature in 5\% (wt/vol) nonfat dried milk in Tris-buffered saline (10 $\mathrm{m} M$ Tris-Base [pH: 7.5]; 100 $\mathrm{m} M \mathrm{NaCl}$ ) plus $0.1 \%$ Tween 20 , and probed with anti PGHS-2 (1:500) in 5\% nonfat dried milk diluted in 0.1\% Tween 20 for $2 \mathrm{~h}$ at room temperature. Blots were then incubated with the secondary antibody (anti-rabbit IgG; 1:5000 dilution in 5\% nonfat dried milk in $0.1 \%$ Tween 20) for $1 \mathrm{~h}$. Proteins were detected by chemiluminescence and analyzed by densitometry (AlphaImager 2000; Alpha Innotech Corporation, San Leandro, CA).

\section{Validations of Northern and Western Blotting}

An experiment was carried out to evaluate the accuracy of densitometry analysis of mRNA. Variable amounts $(0,5,10,20,40$, and $50 \mu \mathrm{g})$ of a single sample of cellular RNA, harvested from bovine endometrial cells, were subjected to Northern blotting and simultaneously probed with cDNAs for PGHS-2 and glyceraldehyde 3-phosphate dehydrogenase (GAPDH). The X-ray film signal intensities were quantified with an Alpha Imager 2000 (Alpha Innotech Corporation). There was a linear increase in signal intensity in response to increasing mRNA concentrations for PGHS-2 ( $\mathrm{Y}=33016$ $+1025.3 \mathrm{X} ; \mathrm{R}^{2}=0.88 ; \mathrm{Y}=$ arbitrary unit of PGHS-2 mRNA; $\mathrm{X}=\mu \mathrm{g}$ of RNA $)$ and $\mathrm{GAPDH}(\mathrm{Y}=69595+2222.5$ $\mathrm{X} ; \mathrm{R}^{2}=0.92 ; \mathrm{Y}=$ arbitrary unit of GAPDH mRNA; $\mathrm{X}=$ $\mu \mathrm{g}$ of mRNA). Adjusting PGHS-2 signal intensity by either the inclusion of GAPDH mRNA as a covariate or the use of the ratio of PGHS-2/GAPDH signal intensities indicated that no differences were detected in the relative amounts of PGHS-2 and GAPDH mRNA between lanes. As expected, inclusion of both RNA amount and GAPDH as a covariate accounted for $98 \%$ of the variability in signal intensity of PGHS-2, and $70 \%$ of the variation was accounted for by the signal intensity of GAPDH as a measurement of differences in RNA loading of the gel $(P<0.05)$. In conclusion, scanning of mRNA signaling intensity gave a linear response, with RNA loading between 5 and $50 \mu \mathrm{g}$ of RNA.

Variable amounts of a single sample of cellular protein $(10,20,35,50,65,80$, and $100 \mu \mathrm{g})$ from PdButreated BEND cells and PGHS-2 protein, as an electrophoresis standard $(6,12,25$, and $50 \mathrm{ng})$, were subjected to Western blotting and probed with antibody for PGHS-2. The X-ray film signal intensities were quantified as mentioned previously. A linear increase was detected in signal intensity in response to increasing protein concentrations for PGHS-2 (Y $=1912.2+72.2$ $\mathrm{X} ; \mathrm{R}^{2}=0.98 ; \mathrm{Y}=$ arbitrary unit of PGHS-2 protein; $\mathrm{X}=$ $\mu \mathrm{g}$ of cellular protein) and PGHS-2 peptide $(\mathrm{Y}=642.1$ $+32.8 \mathrm{X} ; \mathrm{R}^{2}=0.90 ; \mathrm{Y}=$ arbitrary unit of PGHS-2 protein; $\mathrm{X}=\mathrm{ng}$ of PGHS-2 peptide). Following transfer of proteins from gel, membranes were stained with Ponceau-S to monitor transfer efficiency and the gel stained with Coomassie blue to monitor residual protein.

\section{Radioimmunoassays}

Concentrations of $\mathrm{PGF}_{2 \alpha}$ were measured in medium as described by Danet-Desnoyers et al. (1994). The assay was validated for serum-free medium (Binelli et al., 2000). Anti-PGF ${ }_{2 \alpha}$ antiserum used was characterized by Dubois and Bazer (1991) and used at a 1:5000 dilution in Tris buffer. Sensitivity of the assay was 5 $\mathrm{pg}$, and $25 \mu \mathrm{L}$ of media were quantified directly such that minimal amount detected in media was $0.2 \mathrm{ng} /$ $\mathrm{mL}$. Concentrations of $\mathrm{PGE}_{2}$ were measured in culture medium $(25 \mu \mathrm{L})$ by direct radioimmunoassay as described by Gross et al. (1988). The anti-PGE 2 antiserum used was characterized by Dubois and Bazer (1991) and used in the assay at an antibody dilution of 1:5000 for Experiment 1 (BEND cells) and Experiment 3 (primary cells). When assaying $25 \mu \mathrm{L}$ of media, sensitivity of the assay was $5 \mathrm{pg}$ such that $0.20 \mathrm{ng} / \mathrm{mL}$ was the minimal concentration of $\mathrm{PGE}_{2}$ detected. In Experiment 2, sensitivity of the assay was reduced to $50 \mathrm{pg}$ for $\mathrm{PGE}_{2}$ when using a 1:1000 antibody dilution such that the minimal concentration of $\mathrm{PGE}_{2}$ was $2 \mathrm{ng} / \mathrm{mL}$.

\section{Statistical Analyses}

Abundance of PGHS-2 protein in Western blots, PGES, PGHS-2 mRNA in Northern blots, and concentrations of $\mathrm{PGF}_{2 \alpha}$ and $\mathrm{PGE}_{2}$ were analyzed using the GLM procedure (SAS Inst. Inc., Cary NC). Effects of treatments (control, $\mathrm{PdBu}, \mathrm{IFN}-\tau$, and $\mathrm{PdBu}+\mathrm{IFN}-\tau$ ) were tested. Abundance of GAPDH mRNA was used as a covariate to adjust for loading differences in Northern 
blots. Pre-planned orthogonal contrasts were used in the analysis of Experiment 1 to compare treatment means (no PdBu vs. PdBu, no IFN- $\tau$ vs. IFN- $\tau$, and interactions of $\mathrm{PdBu} \times \mathrm{IFN}-\tau$ ). In Experiment 2, concentrations of $\mathrm{PGF}_{2 \alpha}$ and $\mathrm{PGE}_{2}$ were analyzed using the GLM procedure as a factorial experiment of PdBu and IFN- $\tau$ doses.

Concentrations of $\mathrm{PGF}_{2 \alpha}$ and $\mathrm{PGE}_{2}$ from primary cell cultures of Experiment 3 were analyzed as a $2 \times 3$ factorial design of 6 treatments (PdBu [0 and $100 \mathrm{ng} /$ $\mathrm{mL}]$ and IFN- $\tau$ [0, 50, or $500 \mathrm{ng} / \mathrm{mL}])$ using the mixed model procedure of SAS. Cow and cow $\times$ treatment were random variables. Effects of treatment were tested using the cow $\times$ treatment variance.

\section{RESULTS}

\section{Experiment 1: Secretion of $\mathrm{PGF}_{2 \alpha}$ and $\mathrm{PGE}_{2}$ and Expression of PGHS-2 and PGES in Response to PdBu and IFN- $\tau$ in BEND Cells}

Treatment of cells with $\mathrm{PdBu}$ for $6 \mathrm{~h}$ stimulated secretion of $\mathrm{PGF}_{2 \alpha}\left(P<0.05\right.$; Figure 1A) and $\mathrm{PGE}_{2}(P<$ 0.01 ; Figure 1B), which was the major prostaglandin secreted. Treatment with bovine IFN- $\tau(50 \mathrm{ng} / \mathrm{mL})$ blocked the $\mathrm{PdBu}$-induced secretion of both prostaglandins $(P<0.01$; Figure $1, \mathrm{~A}$ and $\mathrm{B})$.

Treatment of BEND cells with $\mathrm{PdBu}$ for $6 \mathrm{~h}$ induced expression of PGHS-2 mRNA $(P<0.01$; Figure 2), PGHS-2 protein $(P<0.01$; Figure 3$)$, and PGES mRNA $(P<0.01$; Figure 4$)$. Concurrent addition of IFN- $\tau$ reduced the PdBu-induced expression of PGHS-2 mRNA $(P<0.01)$, PGHS-2 protein $(P<0.01)$, and PGES mRNA $(P<0.01)$. No stimulatory effect of IFN- $\tau$ was detected on expression of PGHS-2 mRNA, PGES mRNA, and PGHS-2 protein in BEND cells when given in the absence of $\mathrm{PdBu}$.

\section{Experiment 2: Effect of Different Doses of IFN- $\tau$ on $\mathrm{PGF}_{2 \alpha}$ and $\mathrm{PGE}_{2}$ Secretion by BEND Cells}

Treatment of BEND cells with IFN- $\tau$ in the absence of $\mathrm{PdBu}$ did not increase concentrations of either $\mathrm{PGF}_{2 \alpha}$ or $\mathrm{PGE}_{2}$ above the sensitivities of the respective assays. In contrast, cells treated with $\mathrm{PdBu}$ had measurable increases in both $\mathrm{PGF}_{2 \alpha}$ (Figure 5A) and $\mathrm{PGE}_{2}$ (Figure 5B). Doses of IFN- $\tau<5 \mu \mathrm{g} / \mathrm{mL}$ suppressed the PdBustimulated secretions of $\mathrm{PGF}_{2 \alpha}$ and $\mathrm{PGE}_{2}(P<0.05)$. Doses of IFN- $\tau<5 \mu \mathrm{g} / \mathrm{mL}$ did not suppress PdBu-induced secretion of either $\mathrm{PGF}_{2 \alpha}$ or $\mathrm{PGE}_{2}$. Indeed, high doses of 10 and $20 \mu \mathrm{g} / \mathrm{mL}$ stimulated $\mathrm{PGE}_{2}(P<0.05)$.

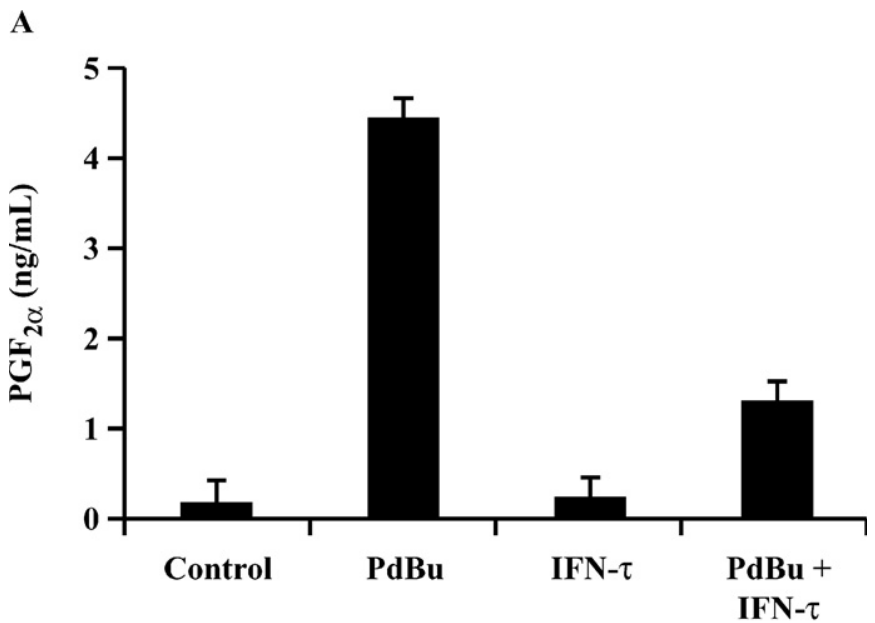

B

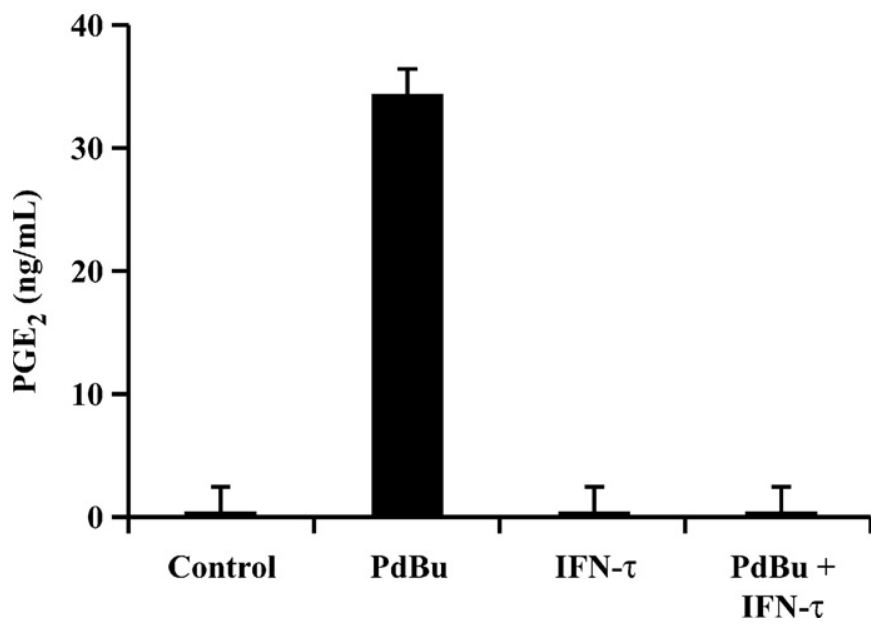

Figure 1. Effects of phorbol 12, 13-dibutyrate (PdBu) and interferon- $\tau(\mathrm{IFN}-\tau)$ on secretion of $\mathrm{A}) \mathrm{PGF}_{2 \alpha}$ and $\mathrm{B}$ ) prostaglandin $\mathrm{E}_{2}$ $\left(\mathrm{PGE}_{2}\right)$ in immortalized bovine endometrial (BEND) cells. Following $24 \mathrm{~h}$ of starvation, BEND cells were treated with $\mathrm{PdBu}(0$ or $100 \mathrm{ng} /$ $\mathrm{mL}$ ) or IFN- $\tau(0$ or $50 \mathrm{ng} / \mathrm{mL}$ ) for $6 \mathrm{~h}$. Least squares means $\pm \mathrm{SEM}$ are presented. Treatment of cells with $\mathrm{PdBu}$ stimulated secretions of prostaglandin $\mathrm{PGF}_{2 \alpha}(P<0.05)$ and $\mathrm{PGE}_{2}(P<0.01)$. Co-treatment of cells with bovine IFN- $\tau$ blocked PdBu-induced secretion of both prostaglandins $(P<0.01)$.

\section{Experiment 3: Effect of PdBu and IFN- $\tau$ on $\mathrm{PGF}_{2 \alpha}$ and $\mathrm{PGE}_{2}$ Secretion by Primary Bovine Epithelial Cells}

Treatment of primary epithelial cells with $\mathrm{PdBu}$ induced $\mathrm{PGF}_{2 \alpha}$ secretion $(P<0.01)$, and IFN- $\tau$ (50 and $500 \mathrm{ng} / \mathrm{mL}$ ) reduced $\mathrm{PGF}_{2 \alpha}$ secretion induced by $\mathrm{PdBu}$ $(P<0.05$; Figure $6 \mathrm{~A})$. In the absence of $\mathrm{PdBu}, \mathrm{IFN}-\tau$ increased basal secretion of $\mathrm{PGF}_{2 \alpha}(P<0.05)$. Concentrations of $\mathrm{PGE}_{2}$ increased in response to $\mathrm{PdBu}(P<$ 0.05; Figure 6B). In the absence of $\mathrm{PdBu}$, the 50-ng/ $\mathrm{mL}$ dose of IFN- $\tau$ had a stimulatory effect on $\mathrm{PGE}_{2}$ concentrations compared with the $500 \mathrm{ng} / \mathrm{mL}$ doses $(P$ 


$\begin{array}{lllllllll}\text { PdBu }(100 \mathrm{ng} / \mathrm{mL}) & - & - & + & + & - & - & + & + \\ \mathrm{IFN}-\tau(50 \mathrm{ng} / \mathrm{mL}) & - & - & - & - & + & + & + & +\end{array}$

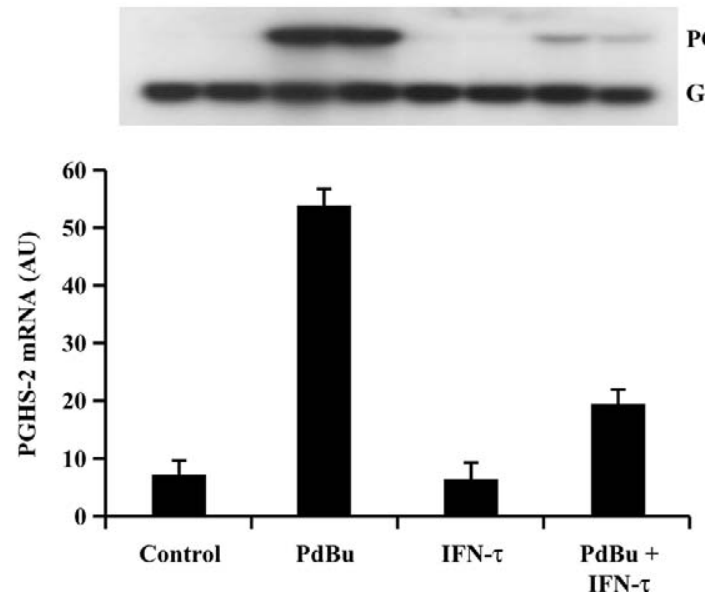

Figure 2. Effects of phorbol 12, 13-dibutyrate (PdBu) and interferon- $\tau(\mathrm{IFN}-\tau)$ on expression of prostaglandin $\mathrm{H}$ synthase-2 (PGHS2) mRNA in immortalized bovine endometrial (BEND) cells. Following $24 \mathrm{~h}$ of starvation, BEND cells were treated with $\mathrm{PdBu}(0$ or 100 $\mathrm{ng} / \mathrm{mL}$ ) and IFN- $\tau(0$ or $50 \mathrm{ng} / \mathrm{mL}$ ) for $6 \mathrm{~h}$. Total RNA was isolated from confluent BEND cells, and $20 \mu \mathrm{g}$ of cellular RNA were fractioned in a $1 \%$ agarose-formaldehyde gel. The blots were hybridized with radiolabeled PGHS-2 cDNA probe. A representative Northern blot is shown. Least square means \pm SEM are presented. Treatment of cells with PdBu stimulated expression of PGHS-2 mRNA $(P<0.01)$. Cotreatment of cells with bovine IFN- $\tau$ blocks $\mathrm{PdBu}$-induced expression of PGHS-2 mRNA $(P<0.01)$. AU = arbitrary unit; GAPDH = glyceraldehyde 3-phosphate dehydrogenase.

$<0.05$; Figure 6B). In contrast to the $\mathrm{PGF}_{2 \alpha}$ response, IFN- $\tau$ failed to decrease the $\mathrm{PGE}_{2}$ secretion in response to $\mathrm{PdBu}$.

\section{DISCUSSION}

The BEND cells were used as model system to study mechanisms related to IFN- $\tau$ regulation of prostaglandin secretion in endometrium, considering such factors as dose of IFN- $\tau$, which vary in early pregnancy. In the present study, PdBu treatment of BEND cells induced PGHS-2 and PGES mRNA and PGHS-2 protein in association with increased secretion of $\mathrm{PGF}_{2 \alpha}$ and $\mathrm{PGE}_{2}$. Interferon- $\tau$ reduced $\mathrm{PdBu}$-induced expression of both PGHS-2 and PGES mRNA, synthesis of PGHS-2 protein, and secretion of both $\mathrm{PGF}_{2 \alpha}$ and $\mathrm{PGE}_{2}$. Both basal and $\mathrm{PdBu}$-induced secretions of $\mathrm{PGE}_{2}$ are greater than that of $\mathrm{PGF}_{2 \alpha}$. Expression of PGHS-2 mRNA is coupled with PGES mRNA expression in a variety of cells (Murakami et al., 2000; Thoren and Jakobsson, 2000; Ivanov et al., 2002). Coupled expression of these enzymes may favor secretion of $\mathrm{PGE}_{2}$ over $\mathrm{PGF}_{2 \alpha}$ because biosynthesis of $\mathrm{PGH}_{2}$, attributable to conversion of arachidonic acid by PGHS-2, would be readily available as substrate for the PGES enzyme. Charpigny et al. (1999) demon-

$\begin{array}{lllllllll}\text { PdBu }(100 \mathrm{ng} / \mathrm{mL}) & - & - & + & + & - & - & + & + \\ \mathrm{IFN}-\tau(50 \mathrm{ng} / \mathrm{mL}) & - & - & - & - & + & + & + & +\end{array}$

PGHS-2

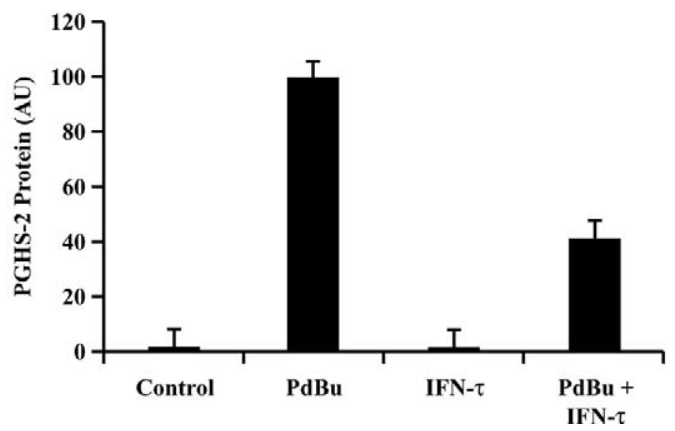

Figure 3. Effects of phorbol 12, 13-dibutyrate (PdBu) and interferon- $\tau(\mathrm{IFN}-\tau)$ on expression of prostaglandin $\mathrm{H}$ synthase-2 (PGHS2 ) protein in immortalized bovine endometrial (BEND) cells. Following $24 \mathrm{~h}$ of starvation, BEND cells were treated with $\mathrm{PdBu}(0$ or 100 $\mathrm{ng} / \mathrm{mL})$ and IFN- $\tau(0$ or $50 \mathrm{ng} / \mathrm{mL})$ for $6 \mathrm{~h}$. Fifty micrograms of protein was loaded onto $7.5 \%$ acrylamide non-reducing gels. Membranes were probed with anti-PGHS-2 (1:500) and anti-rabbit IgG (1:5000). Proteins were detected by an enhanced chemiluminescence kit and analyzed by densitometry. A representative Western blot is shown. Least square means \pm SEM are presented. Treatment of cells with PdBu stimulated expression of PGHS-2 protein $(P<0.01)$. Co-treatment of cells with bovine IFN- $\tau$ blocks PdBu-induced expression of PGHS-2 protein $(P<0.01)$. AU $=$ Arbitrary unit.
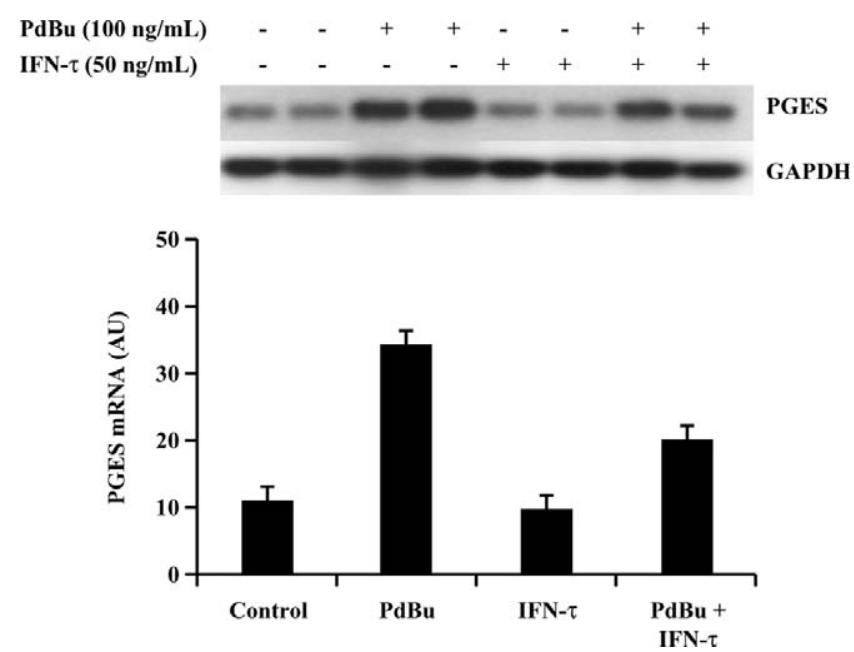

Figure 4. Effects of phorbol 12, 13-dibutyrate (PdBu) and interferon- $\tau($ IFN- $\tau$ ) on expression of prostaglandin E synthase (PGES) mRNA in immortalized bovine endometrial (BEND) cells. Following $24 \mathrm{~h}$ of starvation, BEND cells were treated with $\mathrm{PdBu}(0$ or $100 \mathrm{ng} /$ $\mathrm{mL})$ and IFN- $\tau(0$ or $50 \mathrm{ng} / \mathrm{mL})$ for $6 \mathrm{~h}$. Total RNA was isolated from confluent BEND cells, and $20 \mu \mathrm{g}$ of cellular RNA were fractioned in a $1 \%$ agarose-formaldehyde gel. The blots were hybridized with radiolabeled PGES cDNA probe. A representative Northern blot is shown. Least square means \pm SEM are presented. Treatment of cells with PdBu stimulated expression of PGES mRNA $(P<0.01)$. Cotreatment of cells with bovine IFN- $\tau$ blocks expression of PGES mRNA $(P<0.01) . \mathrm{AU}=$ Arbitrary unit; GAPDH $=$ glyceraldehyde 3 -phosphate dehydrogenase. 
A

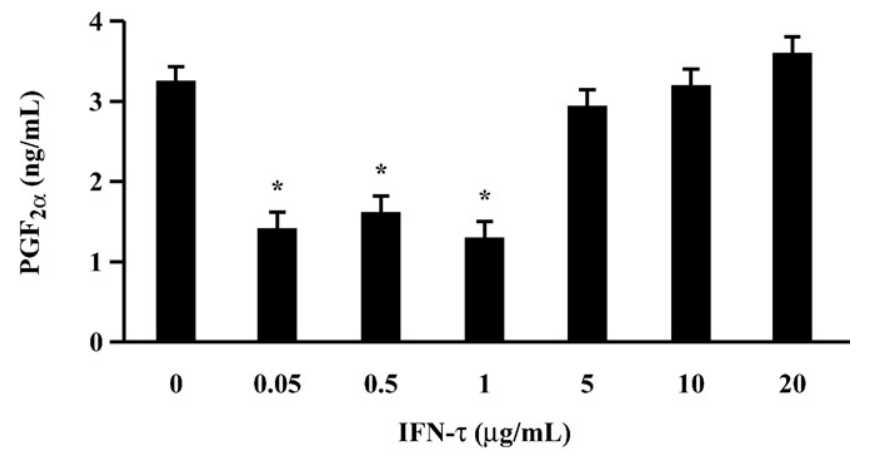

B

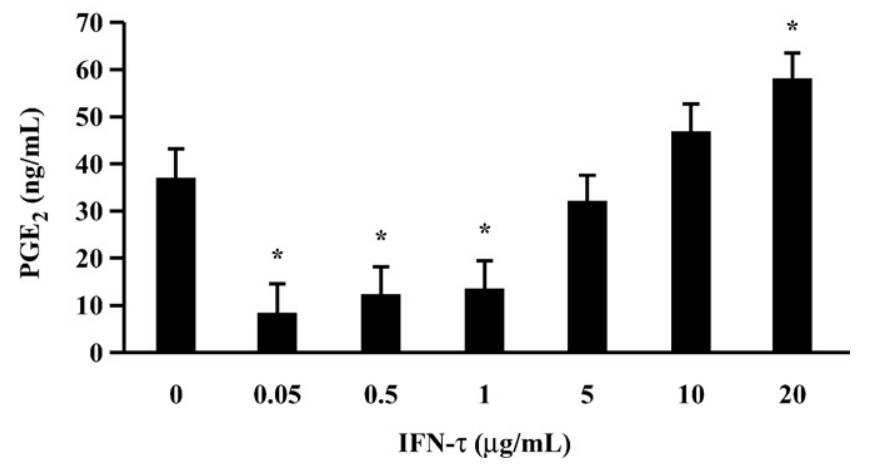

Figure 5. Effects of interferon- $\tau(\mathrm{IFN}-\tau)$ concentrations on A) $\mathrm{PGF}_{2 \alpha}$ and $\left.\mathrm{B}\right)$ prostaglandin $\mathrm{E}_{2}\left(\mathrm{PGE}_{2}\right)$ secretions induced by phorbol 12,13-dibutyrate ( $\mathrm{PdBu}$ ) in immortalized bovine endometrial (BEND) cells. Cells were co-treated with $\mathrm{PdBu}(100 \mathrm{ng} / \mathrm{mL})$ and IFN- $\tau(0$, $0.05,0.5,1,5,10$, and $20 \mu \mathrm{g} / \mathrm{mL}$ ) for $24 \mathrm{~h}$ following starvation. Least square means \pm SEM are presented. IFN- $\tau$ at doses $<5 \mu \mathrm{g} / \mathrm{mL}$ were inhibitory to $\mathrm{PdBu}$-induced secretions of both $\mathrm{PGF}_{2 \alpha}$ and $\mathrm{PGE}_{2}(P<$ 0.05 ), whereas doses $\geq 5 \mu \mathrm{g} / \mathrm{mL}$ were either not inhibitory or stimulatory. ${ }^{*}$ Differs $(P<0.05)$ from others.

strated a clear positive correlation between increased concentration of PGHS-2 enzyme and $\mathrm{PGE}_{2}$ secretion in cultured ovine endometrial epithelial cells. In addition, significant positive correlations were detected between PGHS-2 and PGES mRNA concentrations in bovine endometrial tissue (Arosh et al., 2002). Parent et al. (2003) reported that primary bovine uterine epithelial cells preferentially secreted $\mathrm{PGE}_{2}$ when induced by phorbol ester in contrast to $\mathrm{PGF}_{2 \alpha}$ secretion in response to oxytocin.

Treatment of BEND cells with IFN $-\tau$ at doses $<5 \mu \mathrm{g} /$ $\mathrm{mL}$ reduced both $\mathrm{PGE}_{2}$ and $\mathrm{PGF}_{2 \alpha}$ secretion in response to PdBu. Doses of IFN- $\tau \geq 5 \mu \mathrm{g} / \mathrm{mL}$ did not inhibit $\mathrm{PGF}_{2 \alpha}$ and $\mathrm{PGE}_{2}$ secretion and but stimulated $\mathrm{PGE}_{2}$ secretion in the presence of PdBu. Similarly, Parent et al. (2003) demonstrated in primary cultures of endometrial cells that IFN- $\tau$ variants at doses $\leq 1 \mu \mathrm{g} / \mathrm{mL}$ decreased basal secretions of both $\mathrm{PGF}_{2 \alpha}$ and $\mathrm{PGE}_{2}$, but larger doses of IFN- $\tau$ generally were not inhibitory. At larger doses of 10 and $20 \mu \mathrm{g} / \mathrm{mL}$, the bo-1a isotype of recombinant IFN-
$\mathbf{A}$

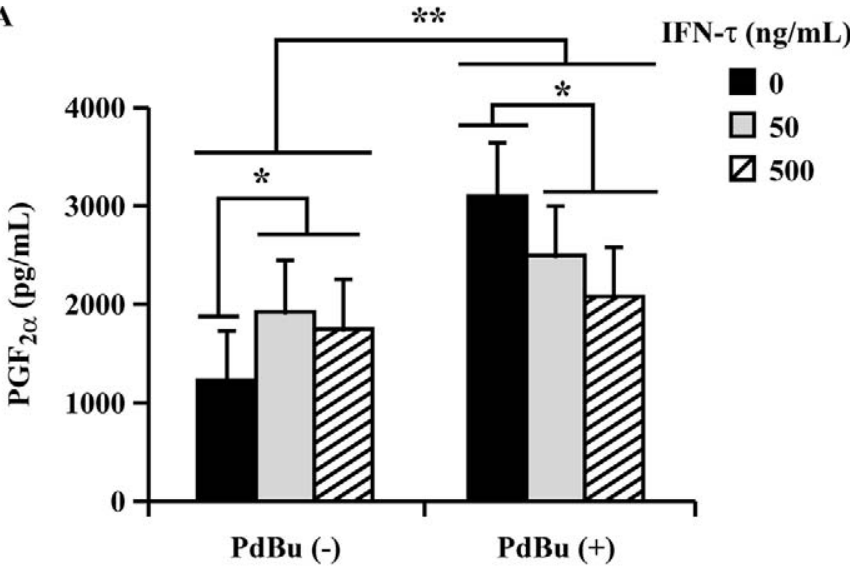

B

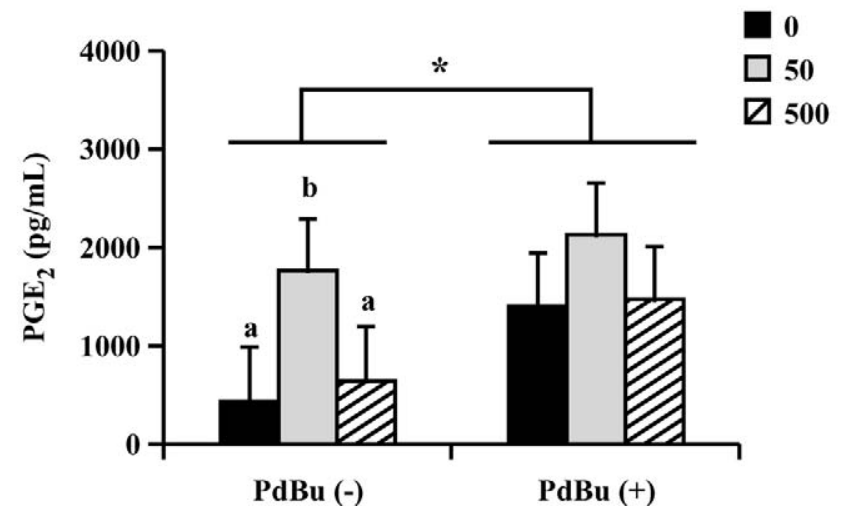

Figure 6. Effects of phorbol 12, 13-dibutyrate $(\mathrm{PdBu})$ and interferon- $\tau(\mathrm{IFN}-\tau)$ on $\mathrm{A}) \mathrm{PGF}_{2 \alpha}$ and B) prostaglandin $\mathrm{E}_{2}\left(\mathrm{PGE}_{2}\right)$ secretions of primary bovine uterine epithelial cells from 7 cows at $d 17$ after estrus. Cells were grown in serum-free media (described in Materials and Methods $)$ and treated with $\mathrm{PdBu}(0$ or $100 \mathrm{ng} / \mathrm{mL})$ and $\operatorname{IFN}-\tau(0$, 50 , or $500 \mathrm{ng} / \mathrm{mL}$ ) for $24 \mathrm{~h}$. Each treatment combination within a cow was triplicated, and least square means \pm SEM are presented. $\left(* P<0.05 ;{ }^{* *} P<0.01 ;{ }^{\mathrm{a}, \mathrm{b}}\right.$ Different superscripts represent differences $[P<0.05]$.)

$\tau$ stimulated basal secretion of prostaglandins and expression of PGHS-2 protein in primary bovine uterine epithelial cells. At a dose of $20 \mu \mathrm{g} / \mathrm{mL}$, bo-1a did not suppress phorbol ester-induced secretion of $\mathrm{PGE}_{2}$. The same IFN- $\tau$ isotype (bovine IFN- $\tau$ 1a) was used in the present experiment, and the stimulatory effect of IFN$\tau$ at the higher doses on $\mathrm{PGF}_{2 \alpha}$ and $\mathrm{PGE}_{2}$ secretions in the presence of $\mathrm{PdBu}$ is likely due to an increased expression of PGHS-2 enzyme in the BEND cells. In the present study with BEND cells, IFN- $\tau$ did not induce prostaglandin secretion to detectable concentrations in the absence of PdBu.

Characterization of the differences in endometrial regulation of prostaglandin secretion between cyclic and pregnant cows and the potential influence of other regulator systems on the luteolytic-antiluteolytic sys- 
tem is vital to development of strategies to stimulate embryo survival. It was reported that IFN- $\tau$ decreased $\mathrm{PGF}_{2 \alpha}$ secretion either in the presence or absence of oxytocin in cultures of primary bovine uterine epithelial cells from d 15 of the estrous cycle (Danet-Desnoyers et al., 1994). In primary cultures of endometrial epithelial cells established from cows during $d 1$ to 3 of the estrous cycle, Asselin and Fortier (2000) demonstrated that low doses of IFN- $\tau$ decreased, and high doses stimulated $\mathrm{PGF}_{2 \alpha}$ secretion. Furthermore, those researchers proposed that IFN- $\tau$ caused a preferential secretion of $\mathrm{PGE}_{2}$ that may be important for maintenance of pregnancy. In BEND cells, small doses of IFN- $\tau$ inhibited $\mathrm{PdBu}$ induction of both $\mathrm{PGF}_{2 \alpha}$ and $\mathrm{PGE}_{2}$ secretion, and large doses stimulated both $\mathrm{PGF}_{2 \alpha}$ and $\mathrm{PGE}_{2}$ secretion with no evidence of a relative preferential increase in $\mathrm{PGE}_{2}$.

To verify the IFN- $\tau$ regulatory responses observed in BEND cells, endometrial epithelial cells from d 17 cyclic cows were treated with $\mathrm{PdBu}$, which also induced $\mathrm{PGF}_{2 \alpha}$ secretion. Treatment with IFN- $\tau$ (50 and $500 \mathrm{ng} /$ $\mathrm{mL}$ ) reduced $\mathrm{PGF}_{2 \alpha}$ secretion induced by $\mathrm{PdBu}$. In the absence of $\mathrm{PdBu}, \mathrm{IFN}-\tau$ increased basal secretion of $\mathrm{PGF}_{2 \alpha}$. These differential changes in $\mathrm{PGF}_{2 \alpha}$ secretion imply dual regulatory effects of IFN- $\tau$ such that basal secretion of $\mathrm{PGF}_{2 \alpha}$ is stimulated through activation of a type I interferon receptor system that is independent of a PdBu activation of PKC. Type I interferons have been shown to activate downstream molecules including $\mathrm{NF} \kappa \mathrm{B}$ (Yang et al., 2001). The PGHS-2 gene contains potential binding sites for $\mathrm{NF} \kappa \mathrm{B}$ in its promoter (Kelly et al., 2001), and interferon-induced activation of $\mathrm{NF} \kappa \mathrm{B}$ could result in induced PGHS-2 gene transcription and increased secretion of prostaglandins. Type II interferons (i.e., IFN- $\tau$ ) and lipopolysaccharide have been shown to induce expression of PGHS-2 gene through the interferon-induced DNA binding protein, IRF-1 (Blanco et al., 2000; Zhang et al., 2002). It was demonstrated that IRF-1 is required for IFN- $\tau$ - and lipopolysaccharide-induced PGHS-2 expression. Similarly, IFN- $\tau$ also induces expression of IRF-1 (Binelli et al., 2001), which could mediate IFN- $\tau$ effects on induced secretion of $\mathrm{PGF}_{2 \alpha}$ in the absence of PdBu. The PGHS2 protein remains expressed in the endometrium obtained from pregnant ewes in contrast to a disappearance in the endometrium of cyclic ewes during the late stages of the estrous cycle (Charpigny et al., 1997). Similarly, on d 17 of the estrous cycle in nonlactating dairy cow, PGHS-2 protein concentration was greater in endometrium of pregnant cows, and PGHS-2 mRNA remained expressed (Guzeloglu et al., 2002; Thatcher et al., 2003). Sustained presence of PGHS-2 in the endometrium likely may be due to presence of IFN- $\tau$ secreted by the conceptus. Spencer et al. (1998) suggested that
IFN- $\tau$ could act directly on the luminal and glandular epithelium of the endometrium during pregnancy to sequentially induce IRF-1 and then interferon regulatory factor-2 gene expression. Although intrauterine infusion of IFN- $\tau$ in cyclic ewes did not effect expression of PGHS-2 mRNA (Kim et al., 2003), it increased endometrial PGHS-2 protein expression in the cow (Emond et al., 2004).

When IFN- $\tau$ was added together with $\mathrm{PdBu}$, the $\mathrm{PdBu}$-induced secretion of $\mathrm{PGF}_{2 \alpha}$ was reduced in primary bovine uterine epithelial cells. The PdBu activates $\mathrm{PKC}$, and the downstream signaling pathway that includes mitogen-activated protein kinases (Pru et al., 2001). The main signaling pathway to induce prostaglandin secretion is activated by oxytocin, and oxytocin effects are mimicked by phorbol ester treatment in vitro. The $\mathrm{PdBu}$ is a membrane-permeable stimulator of PKC that need not bind to a receptor. The PdBu activates PKC downstream from the oxytocin receptor-phosholipase $\mathrm{C}$ system. In cultured endometrial epithelial cells originating from cows at metestrus, $\mathrm{PdBu}$ stimulated secretion of $\mathrm{PGF}_{2 \alpha}$ and expression of PGHS-2 protein (Xiao et al., 1999). The present results, utilizing PdBu-treated BEND cells, support earlier observations of an IFN- $\tau$-induced attenuation of $\mathrm{PGF}_{2 \alpha}$ secretion induced by oxytocin in primary epithelial cells originating from uteri at $\mathrm{d} 15$ of the estrous cycle (Danet-Desnoyers et al., 1994).

Basically, the BEND cells responded to PdBu with increases in the components of the prostaglandin synthetic cascade (i.e., PGHS-2 mRNA and protein, PGES mRNA, $\mathrm{PGF}_{2 \alpha}$, and $\mathrm{PGE}_{2}$ ). Also, IFN- $\tau$ (at doses $<5 \mu \mathrm{g} /$ $\mathrm{mL}$ ) attenuated the secretion of $\mathrm{PGF}_{2 \alpha}$ induced by $\mathrm{PdBu}$ in BEND cells. Because PdBu bypasses the oxytocin receptor associated signaling events upstream of PKC, then IFN- $\tau$ is able to regulate negatively the ability of both primary bovine uterine epithelial and BEND cells to produce prostaglandin following activation of PKC. The PdBu stimulation of the PKC system to increase $\mathrm{PGF}_{2 \alpha}$ and $\mathrm{PGE}_{2}$ secretion was blocked by an IFN- $\tau$ induced attenuation in expression of PGHS-2 and PGES mRNA and a decrease in PGHS-2 protein in BEND cells. In bovine uterine epithelial cells, increased basal secretion of $\mathrm{PGF}_{2 \alpha}$ in response to IFN- $\tau$ represented a smaller increase compared with that of $\mathrm{PdBu}$ alone. The IFN- $\tau$ at high doses of $\geq 5 \mu \mathrm{g} / \mathrm{mL}$ did not inhibit PdBu-induced secretion of prostaglandins in BEND cells.

As previously described, PGHS-2 protein is increased in the endometrial epithelial cells of pregnant cows at d 17 of the estrous cycle (Guzeloglu et al., 2002; Thatcher et al., 2003). Also, Emond et al. (2004) demonstrated that PGHS-2 protein is upregulated in cows during early pregnancy and in response to intrauterine 
infusions of IFN- $\tau$. Thus, IFN- $\tau$ in vivo does not suppress PGHS-2 expression in the endometrium as observed in the cultures of either primary epithelial or BEND cells. However, cells in culture treated with small doses of IFN- $\tau$ (i.e., $<1 \mu \mathrm{g} / \mathrm{mL}$ ) may be at concentrations less than what endometrial cells are exposed to in vivo. The present study in BEND cells, and that by Parent et al. (2003) in primary bovine uterine epithelial cells, demonstrates clearly that the effect of IFN- $\tau$ on the components of prostaglandin synthesis cascade is dose-dependent, with small doses being inhibitory and larger doses being non-inhibitory or stimulatory. A recent study by Okuda et al. (2004) also reports inhibitory effect of IFN- $\tau$ on TNF- $\tau$-induced expression of PGHS2 and $\mathrm{PGF}_{2 \alpha}$ in primary bovine uterine stromal cells. Therefore, 2 distinct effects of IFN- $\tau$ should be considered on prostaglandin secretion by uterine cells.

A high abundance of PGHS-2 protein in the uterus from pregnant cows suggests that an inhibitory action of IFN- $\tau$ on secretion of $\mathrm{PGF}_{2 \alpha}$ may not be at the level of PGHS-2 expression. On d 17 after estrus in cows, the potential luteolytic cascade may be affected as pregnancy decreased steady-state concentrations of estrogen receptor $\alpha$ and oxytocin receptor and increased concentration of PGHS-2 protein (Guzeloglu et al., 2002; Thatcher et al., 2003). A decline in the concentrations of estrogen receptor $\alpha$ and oxytocin receptor possibly suppresses pulsatile secretion of $\mathrm{PGF}_{2 \alpha}$ by endometrium that normally initiates luteolysis. The increase in PGHS-2 protein could contribute to the higher basal concentrations of $\mathrm{PGF}_{2 \alpha}$ metabolite in the circulation (Williams et al., 1983; Mishra et al., 2003). In pregnant mammals, PGHS-2 is needed for pregnancy-associated events, such as regulation of localized immune function, angiogenesis, regulation of blood flow, and development of implantation sites (Lim et al., 1997; Marions and Danielsson, 1999; Matsumoto et al., 2001, 2002). Poorly developed embryos secrete small amounts of IFN- $\tau$ at the time of pregnancy recognition (Mann and Lamming, 2001), which would inhibit the pulsatile secretion of $\mathrm{PGF}_{2 \alpha}$ via an impairment in oxytocin signaling. Pregnancy will not continue because of small amounts of IFN- $\tau$ that cause a decrease in PGHS-2, which is essential for prostaglandin-dependent pregnancy processes. However, the temporary absence of pulsatile secretion of $\mathrm{PGF}_{2 \alpha}$ will cause a delay in corpus luteum regression that is finally overridden by induction of oxytocin receptor as a default in the absence of IFN- $\tau$.

\section{REFERENCES}

Arosh, J. A., J. Parent, P. Chapdelaine, J. Sirois, and M. A. Fortier. 2002. Expression of cyclooxygenases 1 and 2 and prostaglandin E synthase in bovine endometrial tissue during the estrous cycle. Biol. Reprod. 67:161-169.
Asselin, E., D. Lacroix, and M. A. Fortier. 1997. IFN-tau increases $\mathrm{PGE}_{2}$ production and Cox-2 gene expression in the bovine endometrium in vitro. Mol. Cell. Endocrinol. 132:117-126.

Asselin, E., and M. A. Fortier. 2000. Detection and regulation of the messenger for a putative bovine endometrial 9-keto-prostaglandin $\mathrm{E}_{2}$ reductase: Effect of oxytocin and interferon-tau. Biol. Reprod. 62:125-131.

Austin, K. J., S. K. Ward, M. G. Teixeira, V. C. Dean, D. W. Moore, and T. R. Hansen. 1996. Ubiquitin cross-reactive protein is released by the bovine uterus in response to interferon during early pregnancy. Biol. Reprod. 54:600-606.

Badinga, L., A. Guzeloglu, and W. W. Thatcher. 2002. Bovine somatotropin attenuates phorbol-ester-induced prostaglandin $\mathrm{PGF}_{2 \alpha}$ production in bovine endometrial cells. J. Dairy Sci. 85:537-543.

Binelli, M., A. Guzeloglu, L. Badinga, D. R. Arnold, J. Sirois, T. R. Hansen, and W. W. Thatcher. 2000. Interferon- $\tau$ modulates phorbol ester-induced production of prostaglandin and expression of cycloxygenase- 2 and phospholipase- $\mathrm{A}_{2}$ from bovine endometrial cells. Biol. Reprod. 63:417-424.

Binelli, M., P. Subramaniam, T. Diaz, G. A. Johnson, T. R. Hansen, L. Badinga, and W. W. Thatcher. 2001. Bovine interferon- $\tau$ stimulates the janus kinase-signal transducer and activator of transcription pathway in bovine endometrial epithelial cells. Biol. Reprod. 64:654-665.

Blanco, J. C. G., C. Contursi, C. A. Salkowski, D. L. DeWitt, K. Ozato, and S. N. Vogel. 2000. Interferon regulator factor (IRF)-1 and IRF2 regulate interferon $\tau$-dependent cyclooxygenase 2 expression. J. Exp. Med. 191:2131-2144.

Bradford, M. M. 1976. A rapid and sensitive method for the quantitation of microgram quantities of protein utilizing the principle of protein-dye binding. Anal. Biochem. 72:48-54.

Charpigny, G., P. Reinaud, J. P. Tamby, C. Creminon, J. Martal, J. Maclouf, and M. Guillomot. 1997. Expression of cyclooxygenase1 and -2 in ovine endometrium during the estrous cycle and early pregnancy. Endocrinology 138:2163-2171.

Charpigny, G., P. Reinaud, C. Creminon, and J. P. Tamby. 1999. Correlation of increased concentration of ovine endometrial cyclooxygenase 2 with the increase in $\mathrm{PGE}_{2}$ and $\mathrm{PGD}_{2}$ in the luteal phase. J. Reprod. Fertil. 117:315-324.

Danet-Desnoyers, G., C. Wetzels, and W. W. Thatcher. 1994. Natural and recombinant bovine interferons regulate basal and oxytocininduced secretion of $\mathrm{PGF}_{2 \alpha}$ and $\mathrm{PGE}_{2}$ by endometrial epithelial and stromal cells. Reprod. Fertil. Dev. 6:193-202.

Dubois, D. H., and F. W. Bazer. 1991. Effect of porcine conceptus secretory proteins on in vitro secretion of prostaglandin- $\mathrm{F}_{2 \alpha}$ and $\mathrm{E}_{2}$ from luminal and myometrial surfaces of endometrium from cyclic and pseudopregnant gilts. Prostaglandins 41:283-301.

Emond, V., L. A. MacLaren, S. Kimmins, J. A. Arosh, M. A. Fortier, and R. D. Lambert. 2004. Expression of cyclooxygenase-2 and granulocyte-macrophage colony-stimulating factor in the endometrial epithelium of the cow is up-regulated during early pregnancy and in response to intrauterine infusions of interferon- $\tau$. Biol. Reprod. 70:54-64.

Fillion, F., N. Bouchard, A. K. Goff, J. G. Lussier, and J. Sirois. 2001. Molecular cloning and induction of bovine prostaglandin $\mathrm{E}$ synthase by gonadotropins in ovarian follicles prior to ovulation in vivo. J. Biol. Chem. 276:34323-34330.

Gross, T. S., W. W. Thatcher, P. J. Hansen, and S. D. Helmer. 1988. Presence of an intracellular endometrial inhibitor of prostaglandin synthesis during early pregnancy in the cow. Prostaglandins 35:359-378.

Guzeloglu, A., T. Bilby, S. Kamimura, A. Meikle, L. Badinga, A. Dinges, O. Hernandez, and W. W. Thatcher. 2002. Effects of pregnancy and bovine somatotropin (bST) on endometrial gene expression related to maintenance of pregnancy in non-lactating dairy cows. Biol. Reprod. 66(Suppl. 1):314. (Abstr.)

Hansen, T. R., K. J. Austin, and G. A. Johnson. 1997. Transient ubiquitin cross-reactive protein gene expression in bovine endometrium. Endocrinology 138:5079-5082.

Ivanov, A. I., R. S. Pero, A. C. Scheck, and A. A. Romanovsky. 2002. Prostaglandin $\mathrm{E}_{2}$-synthase enzymes in fever: differential tran- 
scriptional regulation. Am. J. Physiol. Regul. Interg. Comp. Physiol. 283:R1104-R1117.

Johnson, G. A., K. J. Austin, A. M. Collins, W. J. Murdoch, and T. R. Hansen. 1999. Endometrial ISG17 mRNA and a related mRNA are induced by interferon tau and localized to glandular epithelial and stromal cells from pregnant cows. Endocrine 10:1-9.

Kelly, R. W., A. E. King, and H. O. D. Critchley. 2001. Cytokine control in human endometrium. Reproduction 121:3-19.

Kim, S., Y. Choi, T. E. Spencer, and F. W. Bazer. 2003. Effects of the estrous cycle, pregnancy and interferon-tau on cyclooxygenase 2 (COX-2) expression in ovine endometrium. Reprod. Biol. Endocrinol. 1:58

Liu, J., M. Antaya, A. K. Goff, D. Boerboom, D. W. Silversides, J. G. Lussier, and J. Sirois. 2001. Molecular characterization of bovine prostaglandin G/H Synthase-2 and regulation on uterine stromal cells. Biol. Reprod. 64:983-991.

Lim, H., B. C. Paria, S. K. Das, K. E. Dinchuk, R. Langenbach, J. M. Trzaskos, and S. K. Dey. 1997. Multiple female reproductive failure in cyclooxygenase 2-deficient mice. Cell 91:197-208.

Mann, G. E., and G. E. Lamming. 2001. Relationship between maternal endocrine environment, early embryo development and inhibition of the luteolytic mechanism in cows. Reproduction 121:175-180.

Marions, L., and K. G. Danielsson. 1999. Expression of cyclo-oxygenase in human endometrium during the implantation period. Mol. Human Reprod. 5:961-965.

Matsumoto, H., M. Wen-Ge, W. Smalley, J. Trzaskos, R. M. Breyer, and S. K. Dey. 2001. Diversification of cyclooxygenase-2-derived prostaglandins in ovulation and implantation. Biol. Reprod. 64:1557-1565.

Matsumoto, H., M. Wen-Ge, T. Daikoku, X. Zhao, B. C. Paria, S. K. Das, J. M. Trzaskos, and S. K. Dey. 2002. Cyclooxygenase-2 differentially directs uterine angiogenesis during implantation in mice. J. Biol. Chem. 277:29260-29267.

Meyer, M. D., P. J. Hansen, W. W. Thatcher, M. Drost, and L. Badinga. 1995. Extension of corpus luteum lifespan and reduction of uterine secretion of prostaglandin $\mathrm{F}_{2 \alpha}$ of cows in response to recombinant interferon- $\tau$. J. Dairy Sci. 78:1921-1931.

Mishra, D. P., H. H. D. Meyer, and B. S. Prakash. 2003. Validation of a sensitive enzymeimmunoassay for 13, 14-dihydro-15-keto$\mathrm{PGF}_{2 \alpha}$ in buffalo plasma and its application for reproductive health status monitoring. Anim. Reprod. Sci. 78:33-46.

Murakami, M., H. Naraba, T. Tanioka, N. Semmyo, Y. Nakatani, F. Kojima, T. Ikeda, M. Fueki, A. Ueno, S. Ohishi, and I. Kudo. 2000. Regulation of prostaglandin $\mathrm{E}_{2}$ biosynthesis by inducible membrane-associated prostaglandin $\mathrm{E}_{2}$ synthase that acts in concert with cyclooxygenase-2. J. Biol. Chem. 275:32783-32792.

Okuda, K., Y. Kasahara, S. Murakami, H. Takahashi, I. WoclawekPotocka, and D. J. Skarzynski. 2004. Interferon- $\tau$ blocks the stimulatory effect of tumor necrosis factor- $\alpha$ on prostaglandin $\mathrm{F}_{2 \alpha}$ synthesis by bovine endometrial stromal cells. Biol. Reprod. 70:191-197.

Parent, J., C. Villeneuve, A. P. Alexenko, A. D. Ealy, and M. A. Fortier. 2003. Influence of different isoforms of recombinant trophoblast interferons on prostaglandin production in cultured bovine endometrial cells. Biol. Reprod. 68:1035-1043.

Perry, D. J., K. J. Austin, and T. R. Hansen. 1999. Cloning of interferon-stimulated gene 17: The promoter and nuclear proteins that regulate transcription. Mol. Endocrinol. 13:1197-1206.

Pru, J. K., B. R. Rueda, K. J. Austin, W. W. Thatcher, A. Guzeloglu, and T. R. Hansen. 2001. Interferon-Tau suppresses prostaglandin $\mathrm{F}_{2 \alpha}$ secretion independently of the mitogen-activated protein kinase and nuclear factor $\kappa \mathrm{B}$ pathways. Biol. Reprod. 64:965-973.

Spencer, T. E., T. L. Ott, and F. W. Bazer. 1998. Expression of interferon regulatory factor one and two in the ovine endometrium: Effects of pregnancy and ovine interferon tau. Biol. Reprod. 58:1154-1162.

Staggs, K. L., K. J. Austin, G. A. Johnson, M. G. Teixerra, C. T. Talbott, V. A. Dooley, and T. R. Hansen. 1998. Complex induction of bovine uterine proteins by interferon-tau. Biol. Reprod. 59:293-297.

Takahashi, H., K. Iga, M. Takahashi, and A. Okana. 2001. Isolation and culture of bovine endometrial epithelial cells in a serum-free culture system. J. Reprod. Dev. 47:181-187.

Thatcher, W. W., A. Guzeloglu, A. Meikle, S. Kamimura, T. Bilby, A. A. Kowalski, L. Badinga, R. A. Pershing, J. Bartolome, and J. E P. Santos. 2003. Regulation of embryo survival in cattle. Reprod. Suppl. 61:253-266.

Thoren, S., and P.-J. Jakobsson. 2000. Coordinate up- and downregulation of glutathione-dependent prostaglandin E synthase and cyclooxygenase-2 in A549 cells. Eur. J. Biochem. 267:6428-6434.

Williams, W. F., G. S. Lewis, W. W. Thatcher, and C. S. Underwood. 1983. Plasma 13, 14-dihydro-15-keto-PGF ${ }_{2 \alpha}$ (PGFM) in pregnant heifers prior to and during surgery and following intrauterine injection of $\mathrm{PGF}_{2 \alpha}$. Prostaglandins 25:891-899.

Yang, C. H., A. Murti, S. R. Pfeffer, J. G. Kim, D. B. Conner, and L. M. Pfeffer. 2001. Interferon $\alpha / \beta$ promotes cell survival by activating nuclear factor $\kappa \mathrm{B}$ through phosphatidylinositol 3-kinase and Akt. J. Biol. Chem. 276:13756-13761

Xiao, C. W., J. M. Liu, J. Sirois, and A. K. Goff. 1998. Regulation of cyclooxygenase-2 and prostaglandin $\mathrm{F}$ synthase gene expression by steroid hormones and interferon- $\tau$ in bovine endometrial cells. Endocrinology 139:2293-2299.

Xiao, C. W., B. D. Murphy, J. Sirois, and A. K. Goff. 1999. Downregulation of oxytocin-induced cyclooxygenase-2 and prostaglandin $\mathrm{F}$ synthase expression by interferon-t in bovine endometrial cells. Biol. Reprod. 60:656-663.

Zhang, S., K. Thomas, J. C. Blanco, C. A. Salkowski, and S. N. Nogel. 2002. The role of the interferon regulatory factors, IRF-1 and IRF-2, in LPS-induced cyclooxygenase-2 (COX-2) expression in vivo and in vitro. J. Endotoxin Res. 8:379-388. 